\title{
THE EFFECT OF HALOTHANE ANAESTHESIA ON LIVER REGENERATION
}

\author{
Vasilios Pratilas, Margaret G. Pratila, and John P. Bramis
}

\begin{abstract}
CURRENT KNOWLEDGE of the effects of anaesthesia on hepatocyte function has substantially influenced surgical practice towards more radical liver surgery. Despite a number of reports advocating the advantages and safety of halothane anaesthesia in extra-hepatic operations, ${ }^{1}$ the alleged hepato-toxicity of halothane has caused reluctance to use this agent in major liver operations. The intention of this study was to investigate whether halothane administered repeatedly and over prolonged periods of time to extensively hepatectomized rats, would influence the process of hepatic regeneration or hepatocyte function. In addition, the effects of halothane on the regenerating liver were compared to the effects of diethyl ether in a controlled trial in inbred rats.
\end{abstract}

\section{Material and Methods}

Forty young adult male Fisher/344 (F) rats (Figure 1) were subjected to 70 per cent hepatectomies under halothane or diethyl ether anaesthesia (20 animals in each group). Halothane anaesthesia was induced with 2 per cent halothane (from a Fluotec vaporizer) in oxygen, using a cone. Anaesthesia for the operation was maintained with one per cent halothane in oxygen, by placing the head of the rat within the cone which was vented to produce a non-rebreathing system. At the end of the operation the rats were placed into a chamber with an entry port through which halothane in oxygen was passed. The chamber had an exit port through which gases were scavenged and there were vents to allow for entry of air. The oxygen content in the chamber was maintained between 30 and 40 per cent by adjust-

Vasilios Pratilas, M.D., Assistant Clinical Professor Mount Sinai School of Medicine. C.U.N.Y., New York, New York; Margaret G. Pratila. M.D., Assistant Clinical Professor, Mount Sinai School of Medicine C.U.N.Y., and Attending Ane sthesiologist, Beth Israe Medical Center, New York. New York; and John P. Bramis, M.D., Assistant Professor, Mount Sina School of Medicine, C.U.N.Y., New York, New York. The Departments of Anesthesiology and Surgery of the Mount Sinai School of Medicine of the City University of New York.

This work was presented in part at the Tenth European Congress of the International College of Surgeons, Milan, Italy, in June 1977.

Canad. Anaesth. Soc. J., vol. 25, no. 4, July 1978 307 ing oxygen flow. Halothane concentration was maintained at one per cent. Concentrations of oxygen and halothane were measured with a Beckman-Pauling meter and a Draeger Narcomed halothane analyser.

Diethyl ether anaesthesia was provided by the same method, using a Vernitrol vaporizer. Concentrations were 20 per cent for induction, and three per cent for maintenance.

Anaesthesia was maintained for the duration of the operation and for eight hours post-operatively. Immediately after hepatectomy the animals were given $3 \mathrm{ml}$ of fresh syngeneic plasma and $3 \mathrm{ml}$ of 10 per cent glucose daily for seven days. The animals which survived 36 and 48 hours after partial hepatectomy were anaesthetized on two more occasions for eight hours and six hours, with their respective agent, for open liver biopsies and blood sampling.

Eight hours before liver biopsies, all hepatectomized animals were injected intravenously with $300 \mathrm{Ci} / \mathrm{kg}$ body weight of 5-iodo-2-deoxyuridine-125I (IUDR), a radioactive precursor of RNA. Normal liver cells as well as hepatocytes from partially resected livers were cultured with ${ }^{3} \mathrm{H}$-thymidine to assay for DNA synthesis. ${ }^{2}$

Liver biopsy specimens were tested for radioactivity in a Picker Autowell Gamma Scintillation Counter and by autoradiography. In addition, formalin-preserved specimens were examined by light microscopy. Standard liver function tests (SGPT, SGOT, bilirubin, and alkaline phosphatase) and measurements of BUN and total serum proteins were done on freshly drawn blood.

Twenty rats matched for the strain, age and sex with the partially hepatectomized animals, received the same type of anaesthesia without hepatectomy and served as controls. Baseline data on liver function and mitotic activity of the hepatocyte were obtained from normal unmodified animals. All data were statistically analyzed with the Mann-Whitney two-tailed rank test.

\section{RESULTS}

There were no differences in the survival rates between extensively hepatectomized animals 


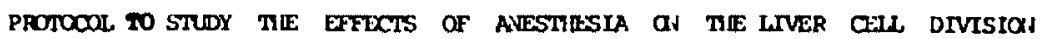

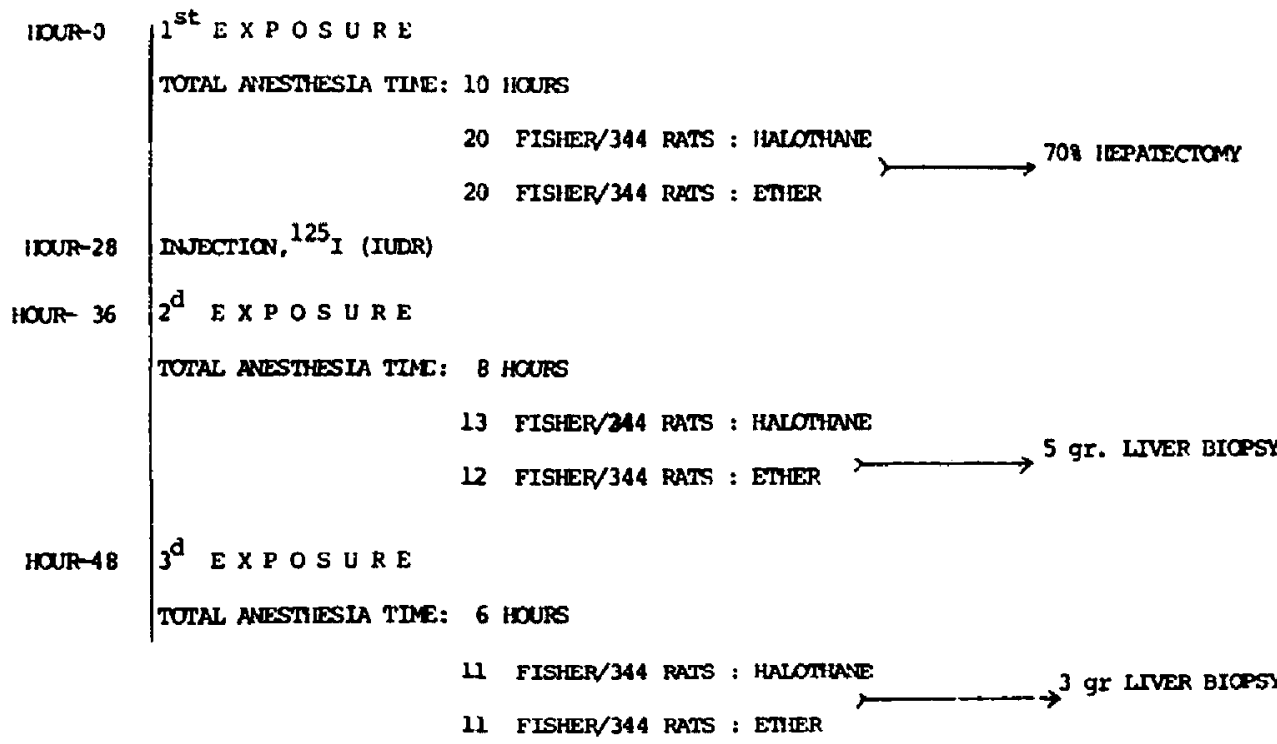

Figure 1. Protocol to study the effects of anaesthesia on hepatic cell division.

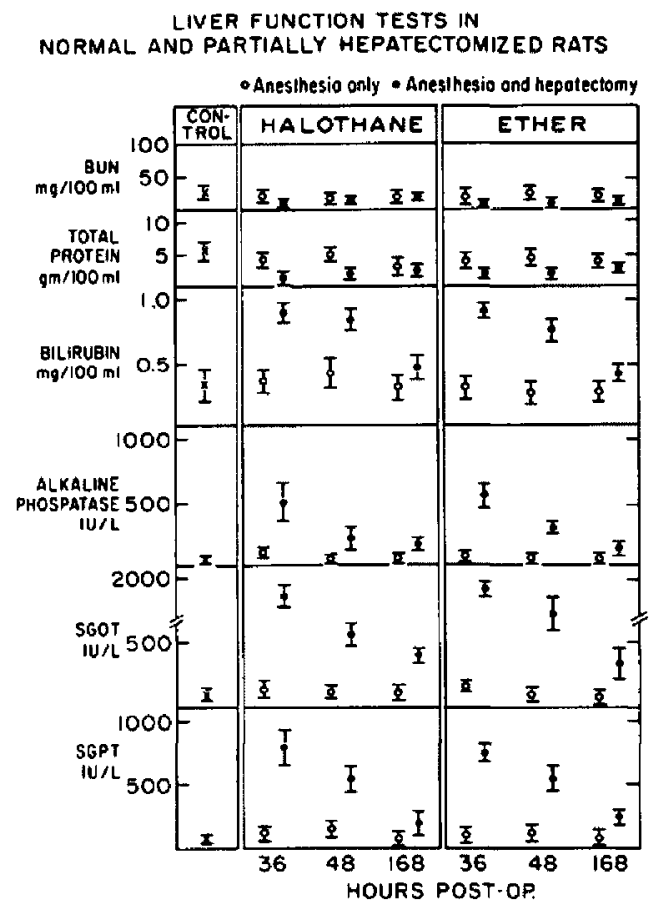

Figure 2 Liver function tests in normal and partially hepatectomized rats. anaesthetized with halothane or diethyl ether. The overall survival rate was 62.5 per cent upon primary exposure and 55 per cent upon secondary exposure. Anaesthesia alone caused no death with either agent.

Abnormal liver function tests were indicative of surgical trauma rather than anaesthetic injury. Alkaline phosphatase, SGPT, SGOT, bilirubin and total proteins were found to be at normal levels in animals anaesthetized repeatedly with either agent without concomitant liver injury. The same tests, but not the BUN, were significantly altered towards abnormal levels during the first 36 to 48 hours after operation, but returned to normal by the end of the first postoperative week. Only SGPT and SGOT though markedly decreased after the first post-operative week, remained at twice the normal levels for prolonged periods of time. However, no differences were observed between diethyl ether and halothane anaesthesia (Figure 2).

Mitotic activity in the liver remnant was not affected by either agent (Figure 3). The mean Mitotic Index (MI = counts/min/gm in hepatectomized rats over counts $/ \mathrm{min} / \mathrm{gm}$ in animals anaesthetized but not hepatectomized $\times 100$ ) was changed only insignificantly in every group of animals compared to normal unmodified controls. The one exception was in those tested 36 


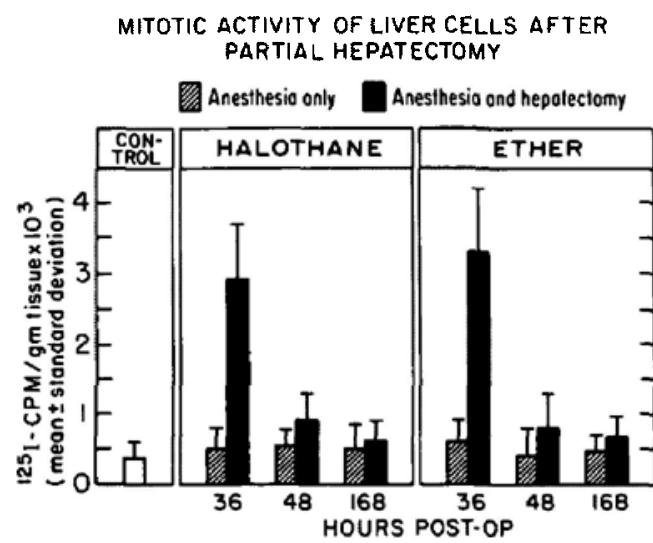

Figure 3 Mitotic activity of liver cells after anaes. thesia only, compared with activity after anaesthesia and partial hepatectomy.

hours after liver resection, when liver regeneration activity exceeded normal values five-fold (5 $\times 10^{3} \pm 2 \times 10^{3} \mathrm{cpm} / \mathrm{gm}$ vs $28 \times 10^{3} \pm 7 \times 10^{3}$ $\mathrm{cpm} / \mathrm{gm}, \mathrm{P}=0.001$ ); however, it was found equal to non-resected livers 48 hours later. Similar data were obtained by histological (Figure 4) and autoradiographic criteria 36 and 48 hours after operation. The influence of diethyl ether or halo. thane anaesthesia was not remarkable in any specimen studied. ${ }^{3} \mathrm{H}$-thymidine incorporation to DNA, in vitro, paralleled the above data with the exception that radioactivity was found to be highest 12 hours earlier ( 24 hours after opera(ion). The type of anaesthesia was not a factor in the process of DNA synthesis.

\section{Discussion}

Regeneration of the human liver has fascinated man from the earliest times. Aeschylus de-

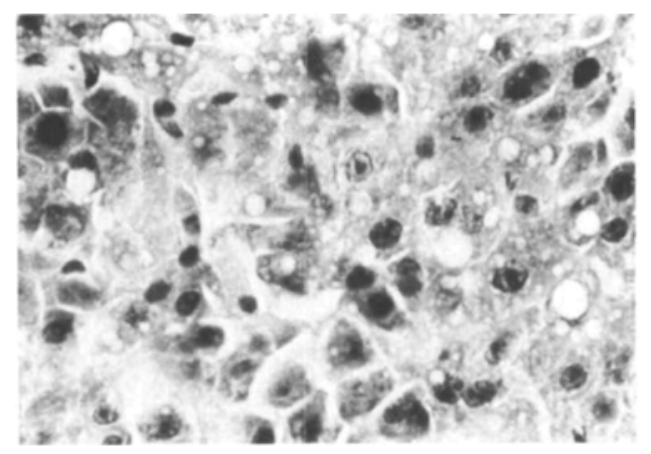

Figure 4 Light microscopy of the liver showing nuclear division unaffected by halothane. scribed, in most accurate terms, the amazing regenerative power of the liver. He told of Prometheus, whose liver was eaten during the day by an eagle, only to grow to its original size each night.

In the last few decades, attempts have been made to elucidate the regulatory mechanisms and the factors involved in liver growth and regeneration after partial hepatectomy. A brief review of the steps which dividing cells undergo is indicated. These steps are (1) division (M phase); (2) postmitotic rest (G1 phase); (3) DNA synthesis, which doubles the nuclear content of DNA (S phase); (4) a brief resting phase (G2 phase). The cell is then ready to divide again.

The flow hypothesis, supported by Child in $1953,{ }^{3}$ was that the quantity of portal blood and not the quality was the only important hepatotrophic influence in the restoration of the hepatic mass. However, the more recent work of Bucher ${ }^{4}$ proved that there is a regenerative or growth factor that stimulates the hepatectomized liver to regenerate. Carotid to jugular cross circulation between partially hepatectomized and nonoperated rats stimulated incorporation of ${ }^{14} \mathrm{C}$ thymidine (a specific DNA precursor) into the hepatic DNA. This occured not only in the hepatectomized rats but also in the non-operated animals.

Generally, loss of liver cells is followed by a proliferative response. At the beginning there is a short lag phase. This is followed by a steep increase in proliferating cells. This comes to a single peak and is followed by decreasing proliferation, until cell loss is fully compensated.s

Increasing evidence suggests that cell formation is influenced by inhibitory substances, the so-called chalones, produced by cells in the proliferative G1 phase of division. They exert their effect on functional G0 cells, maintaining them in a quiescent state. The function of these chalones can be interpreted as allowing adequate body homeostasis by the functional $\mathrm{G} 0$ cells while cells in the $G 1$ phase are replacing lost tissue.

Pre-existing drug-induced hypertrophy enhances the proliferative response of liver parenchymal cells after partial hepatectomy. This has been shown in rats ${ }^{6}$ pretreated with phenobarbitone. Mitotic activity subsequent to partial hepatectomy was markedly increased as compared to the control animals that had not received this drug.

Over thirty years ago Ostergren ${ }^{7}$ showed that nitrous oxide, chloroform, trichlorethylene and diethyl ether caused mitotic arrest in metaphase. 
The appearance was identical to that produced by colchicine and was therefore known as colchicine, or c-mitosis. Nunn ${ }^{8}$ has reported that halothane also produced mitotic arrest of the dividing cells at the root tip of the plant Vicia faba. Again the appearance was identical to that produced by colchicine and would therefore appear to be explained by dispersal of the mitotic spindle. Anderson ${ }^{9}$ has also concluded that volatile anaesthetics inhibit the metaphase portion of mitosis.

The work of Bruce and Traurig ${ }^{10}$ would seem to contradict this. On autoradiographic study, using radioactive thymidine, they found that halothane prolonged the time for epithelial DNA synthesis in the small intestine of the rat. The mitotic phase of the cell was unaffected and only the S-phase of the cell cycle was affected. Snegireff" and his associates also showed depression of mitotic index in the chick embryo neural tube after exposure to 1.2 per cent or 1.6 per cent halothane. Delay of the $S$ phase in the cell cycle alone could account for this depression of the mitotic index.

To add to this complex situation, Grant, et al.,$^{12}$ using the plant Vicia faba, have shown that halothane has a depressant effect on the $M$ phase and also delays or inhibits the passage of cells through the $S$ phase and the $G 2$ phase.

Jackson ${ }^{13}$ studied the effect of halothane on mammalian hepatoma cells in vitro and indicated that halothane does not affect thymidine transport into the hepatoma cells. It either inhibits the process of phosphorylation of intracellular thymidine or the synthetic incorporation of phosphorylated thymidine derivatives into DNA. Ishii and Corbascio ${ }^{14}$ have, however, reported that, in hepatoma and Hella cells, depression of DNA synthesis by halothane was minimal over short periods. Bandoh and Fugita ${ }^{15}$ have shown that clinical concentrations of halothane markedly reduced $3 \mathrm{H}$-thymid ine incorporation into the dividing immunocyte. This resulted in marked suppression of cell division of the immunocyte.

Retardation of the rate of cell growth was seen in cultures of fibroblasts from the lung of Chinese hamsters, on exposure to clinical concentrations of halothane. ${ }^{16}$ This retardation was dose related and affected mainly the Gi phase, but also the $S$ phase. Only small numbers of c-metaphases were seen, and the authors concluded that there was no apparent arrest in metaphase, such as is seen in plants exposed to halothane. The same authors, in a later work, concluded that anaesthetic agents must act on every phase of the cell cycle. ${ }^{17}$
All the work described above was done in plant cells, tissue culture, or intestinal cells. The main organ which halothane is supposed to affect adversely is the liver. We have recently reviewed the literature concerned with experimental or clinical halothane lesions and found no convincing evidence that halothane could be the sole cause of "halothane hepatitis".

Our experiments were designed to study the effect of anaesthesia with clinical concentrations of both halothane and diethyl ether, on the dividing hepatocyte in the rat, following extensive hepatectomy. Halothane is metabolized by $\mathrm{mi}$ crosomal enzymes in the hepatic cells and some of the hypothetical metabolites could be detrimental to it. ${ }^{18}$

In the animal model, the administration of glucose solution and fresh plasma after operation proved to be a successful manoeuvre to ensure satisfactory survival. The disadvantage that rat liver data cannot be directly extrapolated to humans was compensated by the reproducibility of the results, the care in handling the animals and the availability of inbred lines of rats in adequate numbers.

We observed no growth retardation in the liver exposed to halothane or diethyl ether in vivo. This must be attributed to tissue differences or to various biological factors operating in vivo. ${ }^{19} \mathrm{De}$ spite repeated and prolonged exposures to halothane, we did not find histological evidence suggestive of liver damage. In this respect, the present findings are in agreement with recent experimental data in mice. Despite accumulation of halothane metabolites, primarily in the microsomes, there was no evidence of liver toxicity ${ }^{20}$ after repeated ex posures.

\section{SUMmary}

The effects of halothane and diethyl ether on the regenerating liver following 70 per cent hepatectomy were studied in Fisher/344 (F) rats. Our aim was to discover whether halothane administered repeatedly and over prolonged periods could influence the liver regenerative process or hepatocyte function. We also wished to know if the effects of halothane differed from those of diethyl ether.

We found: 1. Prolonged halothane or diethyl ether anaesthesia did not inhibit liver mitotic activity, even if administered repeatedly. 2. The effects of halothane and die thyl ether on liver cell division were identical. 3 . With reference to liver regeneration, halothane is as safe as diethyl ether 
when administered during extensive hepatectomy.

\section{RÉSUMÉ}

L'influence de l'halothane et celle de l'éther diéthylique sur la régénération hépatique après hépatectomie de 70 pour cent a été étudiée chez le rat Fisher 344. Le but de l'étude était de déterminer si des administrations prolongées et répétées d'halothane influençaient la capacité de régénération et la fonction de la cellule hépatique. Nous voulions également savoir si les effets hépatiques de l'halothane étaient différents de ceux de l'èther diéthylique.

Nous avons trouvé: (1) que des anesthésies prolongées et répétées à l'halothane ou à l'éther diéthylique n'inhibent pas l'activité mitotique de la cellule hépatique, (2) que l'influence de l'hatothane sur la division de la cellule hépatique est identique à celle de l'éther et (3) que l'halothane est aussi sécuritaire que l'éther dans les cas d'hépatectomie du point de vue récupération hépatique.

\section{REFERENCES}

1. Cooperman, L.H., Wollman, H., \& Marsh, M.L. Anesthesia and the liver. Surg. Cl. N. Amer. 57: 421-428 (1977).

2. BONNEY, R.J., BECKER, J.E., WALKER, P.R., et al. Primary monolayer cultures of adult rat liver parenchymal cells suitable for study of the regulation of enzyme synthesis. In vitro 9: 399-413 (1974).

3. Child, C.G., Barr, D., Holswade, G.R., et al. Liver regeneration following portocaval transposition in dogs. Ann. Surg. 138: 600-608 (1953).

4. Moolton, F.L. \& BuCHER, N.L.R. Regeneration of rat liver: transfer of humoral agent by cross circulation. Science 158;272-274 (1967).

5. HeINE, W.D. \& KLINGE, O. A hypothesis of growth regulation in liver and other stabile organs. In, Liver Regeneration after Experimental Injury. Ed. Lesch, R, and Reutter, W. New York, Stratton Intercontinental, pp. 320-329 (1975).

6. Japundzic, M., KNezevic, N., DuorduevicCAMBA, V., et al. The influence of phenobar-
bital-Na on the mitotic activity of parenchymal liver cells during rat liver regeneration. Exp. Cell. Res. 48: 163-167 (1967).

7. Ostergren, G. Colchicine mitosis, chromosome contractions, narcosis, and protein chain folding. Hereditas 30:429 (1944).

8. NunN, J.F., Lovis, J.D., \& KIMBALL, K.L. Arrest of mitosis by halothane. Brit. J. Anaesth. 43: $524-530(1971)$.

9. ANDERSON, N.B. The effects of CNS depressants on mitosis. Acta Anaesth. Scand. suppl. 22: 1-36 (1966).

10. Bruce, D.L. \& Traurig, H.H. The effect of halothane on the cell cycle in rat small intestine. Anesthesiology 30: 401-405 (1969).

11. SnegirefF, S.L., Cox, J.R., \& Eastwood, D.W. The effect of nitrous oxide, cyclopropane or halothane on neural tube mitotic index, weight, mortality and gross anomaly rate in the developing chick embryo. In, Toxicity of Anesthetics, Ed. Fink, B.R. Baltimore, Williams \& Wilkins, $p p$. 279-293 (1968).

12. Grant, C.J., Powell, J.N., \& Radford, S.G. Effects of halothane on DNA synthesis and mitosis in root tip meristems of Vicia faba. Brit. J. Anaesth. 46: 653-657 (1974).

13. JACKSON, S.H. The metabolic effects of halothane on mammalian hepatoma cells in viro: 11 lnhibjtion of DNA Synthesis. Anesthesiology 39: 405409 (1973).

14. Ishi, D.N. \& Corbascio, A.N. Some metabolic effects of halothane on mammalian tissue culture cells in vitro. Anesthesiology 34: 427-438 (1971).

15. Bandoh, T.\& FuJITA, T. The suppressive effect of halothane on DNA synthesis of immunocytes. Brit. J. Anaesth. 48: 1129-1133 (1976).

16. Sturrock, J.E. \& NunN, J.F. Effect of anaesthesia on DNA synthesis in Chinese hamster fibroblasts. Brit. J. Anaesth. 46: 316-317 (1974).

17. Sturrock, J.E. \& NunN, J.F, Mitosis in mammalian cells during exposure to anesthetics. Anesthe siology 43: 21-33(1975).

18. Cohen, E.N., Trudell, J.R., Edmunds, H.N., et al. Urinary metabolites of halothane in man. Ane sthe siology 43: 392-401 (1975).

19. LeFFERT, H.L. Growth control of differentiated fetal rat hepatocytes in primary monolayer culture. VII. Hormonal control of DNA synthesis and its possible significance to the problem of liver regeneration. J. Cell. Biol. 62: 792-801 (1974).

20. Stoyka, W.W. \& Havasi, G. The effects of repeated ${ }^{14} \mathrm{C}$-halothane exposure in mice. Canad. Anaesth. Soc. J. 24: 243-251 (1977). 